\title{
Identifying Factors Hindering the Adoption of Expanded Polystyrene for Building Construction in Akure, Nigeria
}

\author{
Victor Momoh, Clement Oluwole Folorunso \\ Department of Architecture, The Federal University of Technology, Akure, Nigeria \\ Email: momohvictor92@gmail.com, cleoconsult2@yahoo.co.uk
}

How to cite this paper: Momoh, V. and Folorunso, C.O. (2018) Identifying Factors Hindering the Adoption of Expanded Polystyrene for Building Construction in Akure, Nigeria. Journal of Materials Science and Chemical Engineering, 6, 1-11. https://doi.org/10.4236/msce.2018.610001

Received: September 18, 2018

Accepted: October 21, 2018

Published: October 24, 2018

Copyright $\odot 2018$ by authors and Scientific Research Publishing Inc. This work is licensed under the Creative Commons Attribution International License (CC BY 4.0).

http://creativecommons.org/licenses/by/4.0/

\begin{abstract}
Housing provision has become a global issue as the need for affordable housing kept increasing in various communities especially in Akure, Nigeria. This has emerged due to various economic, socio-cultural and environmental factors which has increased pressure on conventional building materials thereby leading to the invention of alternative building materials. This paper looks at the barriers to the adoption of expanded polystyrene (EPS) for building construction in Akure, Nigeria. The methodology adopted elicited information through structured questionnaire which assessed the socio-economic characteristics of the respondents, their level of awareness of EPS and its application in building construction, the rate at which they specify EPS for designs and construction and the hindrances to its adoption for building construction. A total of 60 questionnaires were administered on the architects in practice and in the academia environment but 45 were retrieved. This was the bases to which the conclusion of this research was made. The outcome of the research shows that lack of awareness is a key hindrance to the adoption of EPS for construction as most architects in Akure do not know much about expanded polystyrene, thereby, cannot fully decipher its qualities and/or suitability for construction. As such, most questions pertaining the durability, cost implication or client's preference could not be answered by the architects since their knowledge on the subject matter is minimal. However, those who knows about EPS confirms its flexibility, quick construction time and its environmental friendliness but stated that EPS is not readily available like other conventional materials. As such, their specification always goes towards the available materials.
\end{abstract}

\section{Keywords}

Expanded Polystyrene, Sustainability, Housing, Affordability, Construction 


\section{Introduction}

In recent years, conventional materials such as sandcrete block, concrete blocks and burnt bricks have been used to provide housing for shelter and other basic needs. The use of some of these materials have not met the goals of sustainability in building construction due to their high cost of purchase, difficulty in obtaining material due to its limited availability, poor performance and high level of maintenance. These issues have led to the invention of alternative building materials among which are improved plastic material called Expanded Polystyrene (EPS) which offered new options to access a material that is economical and produces structural as well as aesthetics efficiency [1] [2].

Housing has been one of the fundamental needs of human beings just after food and before clothing in order of priority [3]. Public housing provision in Nigeria is still below the required as a result of high cost of conventional building materials and the disregard for alternative methods of housing provision, which make sustainable housing development a mirage in the country [4].

Expanded Polystyrene as an alternative building material is a multipurpose plastic material made available for a multiplicity of applications due to its light weight, buoyancy and it being a good insulator of heat and sound [5] [6] [7] has proclaimed its overwhelming properties and the compatibility of its use in the construction industry yet it is evident that its application in the construction of buildings in Nigeria building industry has not been fully integrated due to inadequate understanding of its usefulness and skeptical overview of its performance. The question now is, why is the adoption of the use of ESP not equivalent to its proclamation as a suitable material for building construction in the area under consideration (Akure, Southwestern Nigeria)? Rather, why are developers/home owners not adopting EPS for construction in the study area?

\section{Related Literature}

\subsection{Expanded Polystyrene (EPS), Properties and Application}

As the world population continues to increase, there has been a great form of imbalance in the demand and supply of houses. Most developing nations of the earth today including Nigeria are exposed to the phenomenon of population growth and scarcity of houses [5]. As a result of this, the demand for affordable infrastructure, basic services and housing in growing urban setup keeps increasing [8]. Therefore, it is expedient to adopt an alternative material with improved quality over the conventional building materials whose use could annex this issue.

Expanded Polystyrene is a thermoplastic material manufactured from styrene monomer, using a polymerization process which produces translucent spherical beads of polystyrene [5]. According to [9], It is derived from the distillation process of crude oil and is $100 \%$ recyclable which makes it an alternative construction material. The five manufacturing stages of expanded polystyrene involves pre-expansion, intermediate conditioning and stabilization, molding, 
shaping and post-production processes [10], grouped into three phases as Pre-expansion, Intermediate maturing and Final Moulding phase [9]. Expanded Polystyrene is regarded for its Economy, Performance and Sustainability [11], recognized among the most important plastic materials, with more than 30 years of application in various functions [12]. It is easy to handle, safe, non-hazardous and has proven constant mechanical and insulation properties for the life time of the building in which it is used [13]. The use of EPS material reduces the rate at which natural materials such as wood and stones are extracted from the environment, thereby promoting sustainable development [9]. It is a stable low-density foam of non-absorbent, hydrophobic, closed cell nature which can be used as ultra-lightweight aggregate suitable for developing concretes for both structural and non-structural applications [14].

[15] observed the features of sustainable building materials. These features are energy efficiency, reduction in construction waste, embodied energy reduction, recycled content, water treatment and conservation, use of non-toxic or less-toxic materials, longer life, reusability and recyclability, renewable energy system, pollution prevention and biodegradability in the pre-building, building and post-building phases and these features are found in this material. Expanded polystyrene material has good strength potentials in building construction and it has performed well for both low and high-rise buildings of up to ten floors, meeting the basic requirements of a building material [6] [9]. The panels have been used in the construction industry to solve problems concerning thermal insulation with the use of additives to give it "self-extinguishing" characteristics and ability to withstand heat or fire for a long period before combustion [6]. Expanded polystyrene does not react with water neither is water absorbed along the walls of the closed cells in the polystyrene foam as compared to masonry stone which can absorb water and become bulky with time when exposed to water [11]. It is non-toxic, chemically inert, non-irritant and rot-proof. Fungi and bacteria cannot grow on EPS and it is insoluble and non-hygroscopic. Also, it is rodent-proof and offers no nutrient attraction to vermin and it is easily recycled [6] [11] [13] making it an alternative material for building construction.

\subsection{Sustainable Building Construction Using Expanded Polystyrene}

Sustainability of buildings is an important issue for the construction industry and are characterized by the lower construction costs for energy consumption and operations, environmentally friendly, able to save natural resources, comfortable and healthy for their users [16]. Safe and affordable housing provides personal, social, and economic benefits, and contributes to the health and safety of individual inhabitants [17]. Energy is one of the most important factors in economic growth and social development in all countries [18], and as urbanization is rapidly growing, the construction of residential area is perpetrating intensely and at the same time the world is also facing the energy resource short- 
age, hence the need to modify the housing design and construction technologies to reduce the cost, gas emission, and to provide more indoor comfort with least energy needs [19] and reduces the effect of diminishing energy resources which is a threat to the present and future of mankind [10].

According to [18] and [20], the building industry uses great quantities of raw materials which involve high energy consumption and that choosing materials with high content in embodied energy entails an initial high level of energy consumption in the building production stage but also determines future energy consumption in order to fulfill heating, ventilation and air conditioning demands. Furthermore, [21] also stated that in the energy efficient building design, the use of energy efficient building materials is very important since the construction materials can positively support the constructions in which they are used by reflecting their environmental features with their all other features into the construction. Based on this, it is important to consider alternative option such as expanded polystyrene or other types of combustible materials for insulation. This is confirmed by [10], where he stated in his study that a great satisfaction was derived by both client and residents of EPS constructed building for its high-ranking performances for recyclability, reliability, versatility and moisture resistance. They also stated that there is a great future for the applications of EPS in the Nigerian building industry. Also [19] said that the use of pre-reinforced Expanded polystyrene sheets will reduce the overall construction cost as it reduces the duration of construction drastically hence the labor cost is reduced consequently which also can be assembled where the bearing capacity of soil is low as the dead weight of the superstructure is very less compared to that of conventional reinforced concrete structure.

Because the expanded polystyrene (EPS) light weight concrete has the characteristics of lightweight, energy absorption, and heat preservation, it is used in many specific construction industries like high rise buildings, floating marine platforms, and large-sized and long-span concrete [17] [21], which is why it should be considered for use in Akure as an alternative building materials to the available alternatives which has demonstrated threat to the sustainability of the immediate surrounding.

\section{Methodology}

Akure is a city in south-western Nigeria, and is the largest city and capital of Ondo State. It comprises of architects in academia and others who either has a firm or practice under a registered firm. Among the registered firms and higher institution in Akure, 60 questionnaires were distributed within the Architects, however 45 were retrieved. This is to ensure that data is collected at random to ascertain rational opinion on the reason why the adoption of ESP for building construction in the study area is low, despite its proclamation by scholars of being a suitable alternative to conventional building materials for building construction. 


\section{Results and Discussion}

The questionnaires were collected and the data was analyzed carefully to decipher the factors hindering the adoption of EPS for building construction in Akure. Below are data analysis, results and discussions;

\subsection{Gender of Respondents}

The respondents in this regard include both Architects in Akure, either in academia or practical field. These respondents are found in the department of Architecture in the higher institutions and in the registered Architectural firms in Akure. From Table 1 below, 73.3\% of the respondents were male architects while $26.7 \%$ were female architects. This is as a result of the low numbers of the female gender in the profession. Data were collected from these respective individuals and were analyzed during the course of the study.

\subsection{Work Experience}

The work experience of the respondents indicates how long the respondents have been in practice. It was observed from Table 2 that a higher percentage of the respondents (53.3\%) have working experience of between 11 - 15 years, $40.1 \%$ had experience of 10 years and below, and $6.6 \%$ of the respondents had experience of 16 years and above. This has significantly influenced the level of exposure of the respondents and diverse options they have had as regards their choice of materials for building construction. This experience will help them to properly evaluate the different building materials and their advantages over one another.

\subsection{Building Construction Executed}

All the respondents have at a time engaged in a sort of building constructions

Table 1. Gender of respondents.

\begin{tabular}{cccc}
\hline S/N & GENDER & FREQUENCY & PERCENTAGE \\
\hline 1 & MALE & 33 & $73.3 \%$ \\
2 & FEMALE & 12 & $26.7 \%$ \\
& TOTAL & 45 & $100.0 \%$ \\
\hline
\end{tabular}

Table 2. Work experience of respondents.

\begin{tabular}{cccc}
\hline S/N & YEARS & FREQUENCY & PERCENTAGE \\
\hline 1 & $0-5$ & 5 & $11.1 \%$ \\
2 & $6-10$ & 13 & $28.9 \%$ \\
3 & $11-15$ & 24 & $53.3 \%$ \\
4 & $16-20$ & 1 & $2.2 \%$ \\
5 & ABOVE 20 & 2 & $4.4 \%$ \\
\hline
\end{tabular}


and the number of buildings constructed by the respondents were noted. As observed from Table 3, quite a higher percentage for respondents (72.3\%) had executed housing project within the range of 11 and above either as a designer, contractor, or consultant. This means that majority of the respondents must have recommended or adopted a material for building construction which may either be expanded polystyrene or other alternatives. The reason for their preferences will be noted.

\subsection{Level of Knowledge of EPS as a Building Material}

The level of knowledge of EPS in this regard means those who knows about its use as a building material, its properties, technical application in construction and its advantage over other materials. These could be acquired either through professional program, thought in higher institutions attended by the respective respondents or through personal studies or informal conversation. Among the respondents, some knew a lot about EPS and could say if it was a better alternative to the conventional materials and the factors that hinders its adoption in Akure.

From Table 4 below, $56.8 \%$ of the respondents do not have the technical knowledge of EPS building construction method. Just a few (21\%) admitted that they have the knowledge of how EPS panels are used for building construction and noted that it is quicker to construct with when compared to sandcrete block or laterite brick especially during the wall erection stage. They noted that they were made aware of this material either in their academic curriculum or in seminars organized by their professional bodies.

Table 3. Building construction executed by respondents.

\begin{tabular}{cccc}
\hline S/N & NUMBERS & FREQUENCY & PERCENTAGE \\
\hline 1 & $0-5$ & 1 & $2.1 \%$ \\
2 & $6-10$ & 7 & $25.6 \%$ \\
3 & $11-15$ & 16 & $35.6 \%$ \\
4 & $16-20$ & 12 & $26.7 \%$ \\
5 & ABOVE 20 & 9 & $10.0 \%$ \\
& TOTAL & 45 & $100.0 \%$ \\
\hline
\end{tabular}

Table 4. Level of knowledge of EPS as a building material.

\begin{tabular}{cccc}
\hline S/N & LEVEL OF KNOWLEDGE & FREQUENCY & PERCENTAGE \\
\hline 1 & VERY HIGH & 1 & $2.2 \%$ \\
2 & HIGH & 26 & $18.8 \%$ \\
3 & MEDIUM & 10 & $22.2 \%$ \\
4 & LOW & 4 & $47.9 \%$ \\
5 & VERY LOW & 4 & $8.9 \%$ \\
& TOTAL & 45 & $100.0 \%$
\end{tabular}




\subsection{Rate of Specification of EPS by Respondents}

The rate at which the architects specifies this material for building construction is low. In Table 5 below, only $2.2 \%$ of the respondents frequently specifies EPS for building construction. $8.9 \%$ specifies it, $48.9 \%$ indicated that they may specify but $40 \%$ indicated not to have specified it before and are not willing to give a try to its use based on factors such as its cost of transport from station to site, its scarce nature in the city and for fear of the unknown in its technical use.

\subsection{Availability of EPS in Akure}

Table 6 assessed the availability of EPS panels in Akure and from the data collected, it was obvious that EPS panels are not readily available in Akure when compared to other conventional building materials. 55.6\% of the respondents noted that EPS cannot be easily reached when needed unlike the sandcrete blocks, laterite bricks and bamboo which are readily available in the study area. However, it can be ordered for and supplied to respective site but it will take more time to get them delivered to stations especially in the case of prompt need thereby making the adoption of the available materials prominent.

\subsection{Cost Implication}

A comparative cost comparison between a set of repeated building construction with the use of EPS panel and sandcrete block at Irese, Akure was the base of the decision made as regards the cost implication of EPS for building construction and the closest to the respondents who knew about its application. These

Table 5. Rate of specification of EPS by respondents.

\begin{tabular}{ccc}
\hline RATE & FREQUENCY & PERCENTAGE \\
\hline VERY FREQUENTLY & 0 & $0 \%$ \\
FREQUENTLY & 1 & $2.2 \%$ \\
NOT AT ALL & 18 & $40.0 \%$ \\
OCCASIONALLY & 4 & $8.9 \%$ \\
MAYBE IN FUTURE & 22 & $48.9 \%$ \\
TOTAL & 45 & $100.0 \%$ \\
\hline
\end{tabular}

Table 6. Availability of EPS in Akure.

\begin{tabular}{cccc}
\hline S/N & RATING & FREQUENCY & PERCENTAGE \\
\hline 1 & STRONGLY AGREE & 1 & $2.2 \%$ \\
2 & AGREE & 1 & $2.2 \%$ \\
3 & NOT SURE & 18 & $40.0 \%$ \\
4 & DISAGREE & 3 & $6.7 \%$ \\
5 & STRONGLY DISAGREE & 22 & $48.9 \%$ \\
& TOTAL & 45 & $100.0 \%$ \\
\hline
\end{tabular}


buildings were of the same design and in the same location. As such could easily be compared. As a result, some respondents were able to say their opinion about the cost implication in relation to other materials. Analysis from data collected in Table 7 implied that majority of the respondents (64.4\%) could not give a specific answer to the comparative cost of EPS panel in relation to other materials since it is not a readily available material in the study area. However, some respondents $(22.2 \%)$ noted that EPS construction is relatively cheap in terms of overall cost of erection when compared to sandcrete block.

\subsection{Quick Construction Time}

From Table 8 below, $42.2 \%$ of the respondents agreed that the construction time when using EPS panel is comparatively faster than when sandcrete block or laterite bricks are used since EPS panel building system has to do with assemblage of panel, installation of services and shotcrete/plastering. Only $17.8 \%$ disagreed to that assertion, that for instant, if the amount of labor is increased or the use of admixtures, the use of other alternative building material could also be fast on the construction site but might as well lead to an increased cost of construction.

\subsection{Environmental Friendliness}

From Table 9, 53.3\% of the respondents could not give an answer to the above question due to low level of knowledge and its usage. However, $42.2 \%$ agreed that EPS panel has a good property of adaptivity with the environment. It provides a cool interior space that complements the harsh weather in Akure,

Table 7. Cost implication.

\begin{tabular}{cccc}
\hline S/N & RATING & FREQUENCY & PERCENTAGE \\
\hline 1 & STRONGLY AGREE & 1 & $2.2 \%$ \\
2 & AGREE & 9 & $20.0 \%$ \\
3 & NOT SURE & 29 & $64.4 \%$ \\
4 & DISAGREE & 3 & $6.7 \%$ \\
5 & STRONGLY DISAGREE & 3 & $6.7 \%$ \\
& TOTAL & 45 & $100.0 \%$ \\
\hline
\end{tabular}

Table 8. Quick construction time.

\begin{tabular}{ccc}
\hline RATING & FREQUENCY & PERCENTAGE \\
\hline STRONGLY AGREE & 10 & $22.2 \%$ \\
AGREE & 9 & $20.0 \%$ \\
NOT SURE & 18 & $40.0 \%$ \\
DISAGREE & 4 & $8.9 \%$ \\
STRONGLY DISAGREE & 4 & $8.9 \%$ \\
TOTAL & 45 & $100.0 \%$
\end{tabular}


Table 9. Environmental friendliness.

\begin{tabular}{cccc}
\hline S/N & RATING & FREQUENCY & PERCENTAGE \\
\hline 1 & STRONGLY AGREE & 15 & $33.3 \%$ \\
2 & AGREE & 4 & $8.9 \%$ \\
3 & NOT SURE & 24 & $53.3 \%$ \\
4 & DISAGREE & 0 & $0 \%$ \\
5 & STRONGLY DISAGREE & 2 & $4.4 \%$ \\
& TOTAL & 45 & $100.0 \%$ \\
\hline
\end{tabular}

poisonous to rodents, light weight and easy to build with and not harmful to human health.

\section{Conclusion and Recommendation}

\subsection{Conclusion}

After relating opinions from concerned literature on the stated issue with the survey carried out in this research, this paper therefore concludes that awareness and availability are the key hindrances to the adoption of EPS for building construction in Akure. Unlike sandcrete block whose production industry could be found in several places in the city, or laterite which is abundant within and around this region, ESP panel production factory or distribution channels are not readily available in Akure, thereby leaving architects and clients to sticking with the available options, which goes with the assertion made by [10] that, despite the eco-friendliness and other advantages of the EPS insulating material, it has been discovered that there is low level of awareness on the part of the building professionals in Nigeria and that the material is not readily available in the market in all the six geo-political zones of the country. If they had it more in abundant, maybe developers would have adopted it more for construction. Also, Architects do not know much about it, as such cannot fully decipher its qualities and/or suitability for building construction. Though some Architects prefer to recommend to use what they are used to and are aware of its shortcomings and how to prevent them rather than subscribing to a new material whose shortcomings are unknown to them.

However, Architects who know about EPS confirms its low construction cost over other conventional building materials, quick construction time and its environmental friendliness but said in an environment where this material is not readily available and less of its awareness is made known to the clients, Architects and other professionals in the construction company, attention will still keep drifting towards the usual and available alternatives except if these deficiencies are bridged.

\subsection{Recommendations}

This study has shown the tremendous advantages of EPS as a building material. 
This material, however is still unknown to many, making its adoption low in Akure. As a result of this, the following recommendations are made:

- Introduction of the expanded polystyrene to the academic scheme to expose undergraduates to the knowledge of EPS and its properties.

- Introduction of EPS to professional courses to enlighten the architects and other professionals on the use of EPS for building construction.

- Provision of local factories that can make EPS readily available for construction in more locations aside the major cities.

- The architects should enlighten their clients about EPS and probably encourage them to adopt it for their building construction.

Government should make new housing policies that will encourage the use of EPS for construction and should lay an example by carrying out massive construction (estate construction other building for other facilities) using EPS as the building material.

\section{Conflicts of Interest}

The authors declare no conflicts of interest regarding the publication of this paper.

\section{References}

[1] Chen, B. and Liu, J. (2007) Mechanical Properties of Polymer-Modified Concretes Containing Expanded Polystyrene Beads. Construction and Building Materials, 21, 7-11.

[2] Gnip, I.Y., Kersulis, V., Vejelis, S. and Vaitkus, S. (2006) Water Absorption of Expanded Polystyrene Boards. Polymer Testing, 25, 635-641.

[3] Arayela, O. (2005) Developing Appropriate Housing Construction Technology for Medium and Low-Income Earners in Africa: Focus on Nigeria. Africa Union of Architects Conference, 10-11.

[4] Olawuyi, B.J. and Babafemi, A.J. (2009) Performance Evaluation of Polystyrene Walling Units. Ife Journal of Environmental Design and Management, 2, 54-59.

[5] Ede, A.N., Alegiuno, V. and Awoyera, P.O. (2014) Use of Advanced Plastic Materials in Nigeria: Performance Assessment of Expanded Polystyrene Building Technology System. American Journal of Engineering Research, 3, 301-308.

[6] Ibrahim, D., Bankole, O.C., Ma'aji, S.A., Ohize, E.J. and Abdul, B.K. (2013) Assessment of the Strength Properties of Polystyrene Material Used in Building Construction in Mbora District of Abuja, Nigeria. International Journal of Engineering Research and Development, 6, 1-5.

[7] Omolola, O.O. (2014) Laterite Building Material and Sustainable Housing Production in Nigeria. Merit Research Journal of Environmental Science and Toxicology, 2, 39-43.

[8] Ede, A.N. (2015) Acceptability of Plastic Materials for Structural Applications in Nigerian Buildings. International Journal of Innovative Research in Advanced Engineering, 3, 1-6.

[9] Ngugi, H.N., Kaluli, J.W. and Abiero-Gariy, Z. (2017) Use of Expanded Polystyrene Technology and Materials Recycling for Building Construction in Kenya. American Journal of Engineering and Technology Management, 2, 64-71. 
[10] Ogundiran, I.A. and Adedeji, Y.M.D. (2014) Comparative Advantages of Expanded Polystyrene Fascia in Housing Delivery in Nigeria. Civil and Environmental Research, 6, 1-3.

[11] EPS Briefing for Architects, Architectural Technicians, Building and Construction Specifiers (2012) EPS Construction Group 6 Bath Place, Rivington Street, London. Designed and produced by P.R. Principles Ltd, Nottingham, England.

[12] Gitau, N.S. (2014) Student Research Thesis; to Investigate the Extent of Use of Expanded Polystyrene Panels for Building Construction in Kenya (Unpublished) 11-15.

[13] European Manufacturers of Expanded Polystyrene (2009) Sustainable Construction with EPS Insulation.

[14] Saradhi, D., Babu, G.B. and Wee, T.H. (2005) Properties of Lightweight Expanded Polystyrene Aggregate Concrete containing Fly Ash. Cement and Concrete Research, 35, 1218-1223.

[15] Kim, J. and Brenda Rigdon, B. (1998) Sustainable Architecture Module: Qualities, Use, and Examples of Sustainable Building Materials. College of Architecture and Urban Planning, University of Michigan, 14-16.

[16] Mesaros, P., Spisakova, M., Kyjakova, L. and Mandicak, T. (2015) Expanded Polystyrene as the Bearing Building Material of Low Energy Construction. IOP Conference Series, 71, Article ID: 012002.

[17] Shi, W., Miao, L., Luo, J., Wang, J. and Chen, Y. (2015) Durability of Modified Expanded Polystyrene Concrete after Dynamic Cyclic Loading.

[18] Yüksek, I. (2014) The Evaluation of Building Materials in Terms of Energy Efficiency. Creative Commons Attribution, 59, 45-58.

[19] Raj, R., Nayak, M.K., Akbari, M.A. and Sah, P. (2014) Prospects of Expanded Polystyrene Sheet as Green Building Material. International Journal of Civil Engineering Research, 5, 145-150. http://www.ripublication.com/ijcer.htm

[20] Bribián, I.Z., Capilla, A.V. and Usón, A.A. (2010) Life Cycle Assessment of Building Materials: Comparative Analysis of Energy and Environmental Impacts and Evaluation of the Eco-Efficiency Improvement Potential. Building and Environment, 46, 1133-1140.

[21] Kumm, M., Söderström, M.J. and Lönnermark, A. (2013) EPS Insulated Façade Fires from a Fire and Rescue Perspective. MATEC Web of Conferences, 9, Article ID: 05003. https://doi.org/10.1051/matecconf/20130905003 